\title{
Penyakit Arteri Koroner: Pilih CABG atau PCI?
}

\author{
Yoga Yuniadi
}

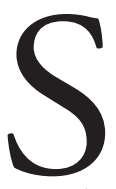

trategi revaskularisasi pada penyakit arteri koroner (PAK) terus menjadi bahan debat di kalangan kardiologi. Berbagai uji klinis yang telah dilakukan menunjukkan hasil yang bervariasi dan harus ditelaah secara detil karena persoalan strategi revaskularisasi menjadi masalah yang tidak sederhana tetapi harus memperhatikan subset pasien yang befvariasi untuk mendapatkan hasil yang terbaik. Prinsip dasar yang harus tetap dijaga oleh para kardiolog adalah keputusan medis harus berorientasi pada pasien. Patient first!

Perbandingan secara tidak langsung antara bedah pintas arteri koroner (BPAK/CABG) dengan intervensi koroner perkutan (IKP/PCI) menunjukkan dengan CABG keperluan pengulangan revaskularisasi lebih sedikit. Masalah yang selalu dipertanyakan dalam membandingkan kedua teknik revaskularisasi itu adalah pengaruh perkembangan teknologi stent terhadap luaran pasien. Berbeda dengan teknik CABG relatif tidak banyak berubah yaitu terdiri dari teknik on- atau off-pump, sedangkan teknologi stent berkembang cepat dan mungkin akan memberikan luaran yang berbeda karena stent generasi terakhir dipercaya memiliki patency rate yang lebih baik. Teknologi stent berkembang dari bare-metal stent ke drug-eluting stent, kemudian drug eluting stent juga berevolusi mulai dari generasi pertama yang memakai obat sirolimus atau paclitaxel ke generasi kedua yang

\section{Alamat Korespondensi}

Dr. dr. Yoga Yuniadi, SpJP. Divisi Aritmia, Departemen Kardiologi dan Kedokteran Vaskular, FKUI dan Pusat Jantung Nasional Harapan Kita, Jakarta. E-mail: yogayl36@gmail.com memakai obat everolimus atau zotarolimus. Demikian juga farmako-teknologi polymer yang berkembang ke arah polymer-free stent. Dalam hal platform stent dimulai dari stainless steel, cobalt chromium, platinum dan terakhir memakai polylactyic acid yang dapat diserap.

Perbandingan antara CABG dengan PCI pada generasi stent pertama telah dilakukan pada beberapa uji klinis, yaitu antara lain FREEDOM (Future Revascularization Evaluation in Patients With Diabetes Mellitus: Optimal Management of Multivessel Disease), SYNTAX (Between Percutaneous Coronary Intervention With Taxus and Cardiac Surgery), CARDia (Coronary Artery Revascularization in Diabetes). Metaanalisis dari tujuh uji klinis menyimpulkan bahwa CABG lebih efektif dibandingkan PCI memakai drug-eluting stent generasi pertama pada pasien dengan LMD dan MVD. CABG lebih unggul dalam hal menurunkan $\mathrm{CABG}$ risikomortalitas (RR: $0.70,95 \% \mathrm{CI}: 0.57$ - 0.87), infark miokard (RR: $0.47,95 \%$ CI: 0.36 to 0.61 ), dan pengulangan revascularisasi (RR: $0.36,95 \% \mathrm{CI}: 0.24$ to 0.52 ), tetapi terjadi peningkatan kejadian stroke (RR: 1.72 , $95 \%$ CI: 1.02 to 2.90$).{ }^{1}$

Kalangan kardiologi sering berpendapat bahwa kemajuan teknologi stent yang pesat mungkin akan mengubah luaran PCI. Tapi apakah benar drug-eluting stent generasi kedua memberikan hasil yang lebih baik daripada generasi pertama jika dibandingkan CABG? Maka untuk menjawab pertanyaan ini, baru-baru ini telah dipublikasikan uji klinis dan studi observasional registri yang dapat menjadi bahan pertimbangan tambahan para kardiolog. Bangalore $\mathrm{dk}^{2}$ menganalisis data registri pasien dengan penyakit multivessel dimana 9223 pasien yang dilakukan PCI memakai everolimuseluting stent dan 9223 pasien yang dilakukan CABG 

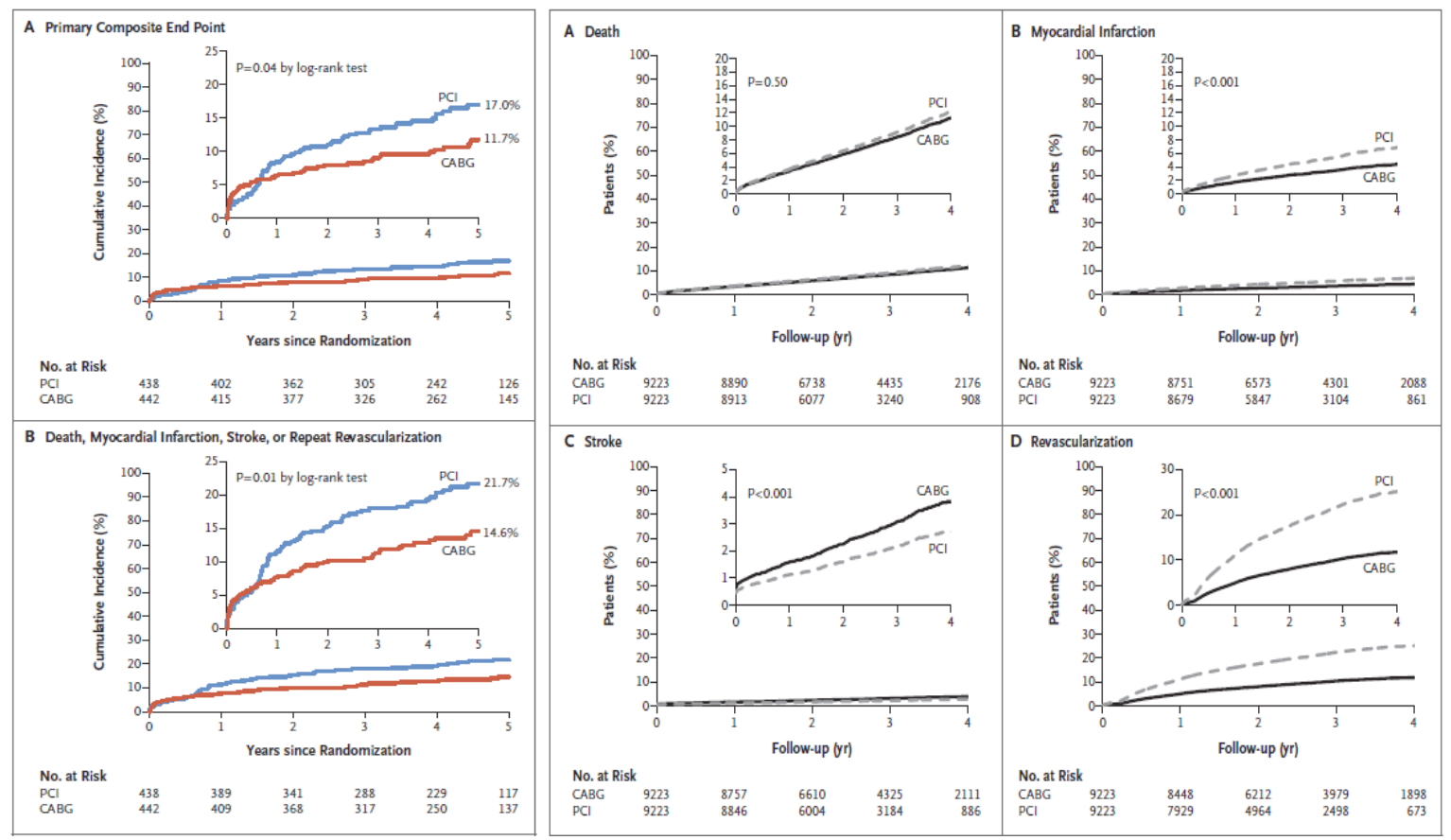

Gambar grafik Kaplan Meier perbandingan CABG dengan PCI. Panel kiri A adalah insiden kumulatif primary composite end point yang terdiri dari kematian, infark miokard atau revaskularisasi pembuluh target. Panel kiri B adalah secondary composite end point yaitu kematian, infark miokard, stroke dan pengulangan revaskularisasi. (Dikutip dari kepustakaan no 3). Panel kanan menunjukkan risiko kumulatif kematian (A), infark miokard (B), stroke (C) dan revaskularisasi (D) pada studi Bangalore dkk. ${ }^{2}$

diobservasi selama rerata 2.9 tahun. Didapatkan risiko kematian yang setara pada kedua kelompok. Pada kelompok PCI didapatkan risiko infark miokard yang lebih tinggi (1.9\% per tahun vs. $1.1 \%$ per tahun; hazard ratio, $1.51 ; 95 \% \mathrm{CI}, 1.29$ sampai $1.77 ; \mathrm{P}<0.001$ ) yaitu pada pasien yang dilakukan revaskularisasi yang tidak lengkap. Kelompok PCI juga lebih sering dilakukan pengulangan revaskularisasi $(7.2 \%$ per tahun vs. 3.1\% per tahun; hazard ratio, 2.35; 95\% CI, 2.14 sampai 2.58; $\mathrm{P}<0.001)$. Tetapi kejadian stroke lebih rendah pada kelompok PCI $(0.7 \%$ per tahun vs. $1.0 \%$ per tahun; hazard ratio, 0.62 ; $95 \% \mathrm{CI}, 0.50$ sampai 0.76 ; $\mathrm{P}<0.001)$. Sementara itu Park $\mathrm{dkk}^{3}$ melakukan suatu uji klinis non-inferioriti acak terkontrol dengan 438 pasien dilakukan PCI memkai everolimus-eluting stent dan 442 dilakukan CABG. Dalam observasi selama 2 tahun, gabungan kejadian kematian, infark miokard atau revaskularisasi pembuluh target didapatkan $11 \%$ pada kelompok PCI tidak non-inferior dibanding 7.9\% pada kelompok CABG. Akan tetapi pada observasi yang lebih lama yaitu median 4.6 tahun kejadian tersebut lebih tinggi pada kelompok PCI (15.3\% vs. 10.6\%; hazard ratio, 1.47 ; 95\% $\mathrm{CI}, 1.01$ to 2.13 ; $\mathrm{P}=0.04$ ) yang terutama disebabkan lebih seringnya revaskularisasi pembuluh target pada kelompok PCI.

Walaupun kedua penelitian diatas cukup penting dalam menambah data tentang metoda revaskularisasi yang paling tepat bagi pasien dengan MVD tetapi para ahli masih melihat ada beberapa kelemahan. Studi oleh Bangalore dkk merupakan suatu studi observasional yang dianggap tidak memadai untuk suatu perbandingan yang kuat. Sedangkan studi Park dkk dianggap kurang sempurna karena besar sampel yang ditetapkan tidak terpenuhi. Harington mengatakan bahwa dua penelitian di atas menunjukkan pentingnya mendiskusikan pilihan strategi revaskularisasi dengan pasien. Risiko stroke yang lebih besar pada CABG mungkin tidak dapat diterima oleh sebagian pasien, sementara sebagian pasien lain justru ingin menghindari risiko pengulangan revaskularisasi atau risiko mengalami infark miokard yang lebih sering bila dilakukan PCI. ${ }^{4}$ Kedua studi diatas memberi sejumlah informasi baru tetapi masih menyisakan pintu debat mengenai cara terbaik revaskularisasi pasien kita. 
Rekomendasi pemilihan antara CABG atau PCI harus dilakukan secara individual dan tetap mengacu pada bukti ilmiah yang tersedia. Penilaian berbagai variabel klinis harus dilakukan dengan hati-hati meliputi keadaan umum, skor SYNTAX anatomi, umur, komorbid, fungsi ginjal, staus mental dan syaraf, serta kepatuhan terapi dual antiplatelet jangka panjang. Disamping itu, harapan dan kecenderungan pasien juga penting dihormati. CABG dan PCI harus lebih didudukan sebagi dua teknik yang saling melengkapi daripada saling berkompetisi. Tim jantung yang terdiri dari kardiolog dan dokter bedah toraks seyogyanya dibentuk untuk mendapatkan pilihan strategi revaskularisasi terbaik bagi pasien. Sekali lagi: patient first!

\section{Daftar Pustaka}

1. Al Ali J, Franck C, Filion KB, Eisenberg MJ. Coronary artery bypass graft surgery versus percutaneous coronary intervention with first-generation drug-eluting stents: a meta-analysis of randomized controlled trials. JACC Cardiovasc Interv 2014;7(5):497-506.

2. Bangalore S, Guo Y, Samadashvili Z, Blecker S, Xu J, Hannan EL. Everolimus-eluting stents or bypass surgery for multivessel coronary disease. N Engl J Med 2015;372(13):1213-22.

3. Park SJ, Ahn JM, Kim YH, Park DW, Yun SC, Lee JY, et al. Trial of everolimus-eluting stents or bypass surgery for coronary disease. N Engl J Med 2015;372(13):1204-12.

4. Harrington RA. Selecting revascularization strategies in patients with coronary disease. N Engl J Med 2015;372(13):1261-3. 